\title{
SMALL AND LARGE SETTLEMENTS OF THE MIERZANOWICE CULTURE IN THE UPLANDS OF WESTERN MAŁOPOLSKA REGION
}

\author{
J A C E K G ÓR S K I
}

\begin{abstract}
In the area of loess uplands in Krakow region, particularly in the light of recent discoveries preceding big road investments, the size and organization of settlements of the Mierzanowice culture seem to be much diversified. The analysis of Mierzanowice culture settlements examined on a large scale shows a great diversity of forms in settlement organization lacking one specific spatial layout pattern. Those differences are not dependent on chronology. The sizes of settlements are diversified - from single farmsteads to organized multi-farmstead structures. Farmsteads can be represented not only by one cellar/pit but also by a few or dozen of objects.
\end{abstract}

Keywords: Western Małopolska, Early Bronze Age, Mierzanowice culture, settlements, loess uplands in Krakow region.

One of the main issues concerning studies on the Mierzanowice culture is archaeological analysis of settlements. In one of the first synthetic studies Jan Machnik pointed out two basic types of settlements, writing 'about settlements remains in the form of pits and concentrations of artefacts on dunes and sandy areas. In this last case only seasonal camps or places of temporary short-term human habitation can be regarded' (Machnik 1967, 18). Evaluating above-mentioned observations from present perspective, one can assume that registered differences are most likely the consequence of different economic bases of communities inhabiting diversified ecosystems. 'Ecological' criterion seems to work out well in the uplands of South-Eastern Poland. The presence of stable large settlements is typical for fertile loess regions. Small and short-term settlements are found on areas with the majority of poorer soils produced on sands, which in loess environment of Southern Poland create enclosed areas.

And yet, the picture of human settlement is not dualistic. In the area of loess uplands in Krakow region, particularly in the light of recent discoveries preceding big road investments, the size and organization of settlements of the Mierzanowice culture seem to be much diversified. Before 'the highway investigations époque', with the exception of Iwanowice microregion (Kadrow 1991; Kadrow/Machnik/Machnik 1992) the knowledge of those issues was based mostly on the analysis of settlements sizes known mostly from field surveys (Rydzewski 1986, 132-140). The analysis of settlements network showed that the sites are concentrated in some regions creating microregion systems. Their elements are central settlements, inhabited for a long time. They were situated usually in up- per parts of an area (Iwanowice, Szarbia Zwierzyniecka: Kadrow 1995, 33-45). Less numerous than it seemed (see Rydzewski 1986, 137-140) are stable settlements situated in lower parts of an area. As an example can serve a large settlement of the Pleszów group at Nowa Huta-Pleszów situated on Vistula terrace (Madej 1988). In related literature one can find short mentions about short-term settlements with a small number of objects and artefacts. They were situated both in the highlands (Szczotkowice: Kruk 1973, 196) and in river valleys (Dziekanowice: Jaśkowiak 1999).

Analyzing settlements sizes, its range estimated during field surveys was taken into account. However, the size of settlement is a sum of subsequent activities from various phases. That's why Sławomir Kadrow's study on settlement investigated on a large-scale at Iwanowice, site Babia Góra (Kadrow 1991) appeared to be critical. Applying suitable research procedures, he succeeded in isolation real settlements units defined as building phases. After quoted author, it should be assumed, that a household is the smallest and basic settlement structure. A group of simultaneous farmsteads form a building phase, i.e. in fact, settlement functioning at one time. A sum of activity remains from different building phases form an area of a multiphase settlement.

Undertaking prior large-scale archaeological investigations seem to be a condition to reconstruct spatial systems of prehistoric settlements. Such works were carried out in association with the construction of A4 Motorway in Krakow area. Mainly relying on its results one can verify theories about ranges of 'large' and 'small' settlements of the Mierzanowice culture. Analyzed settlements will be stated below. 


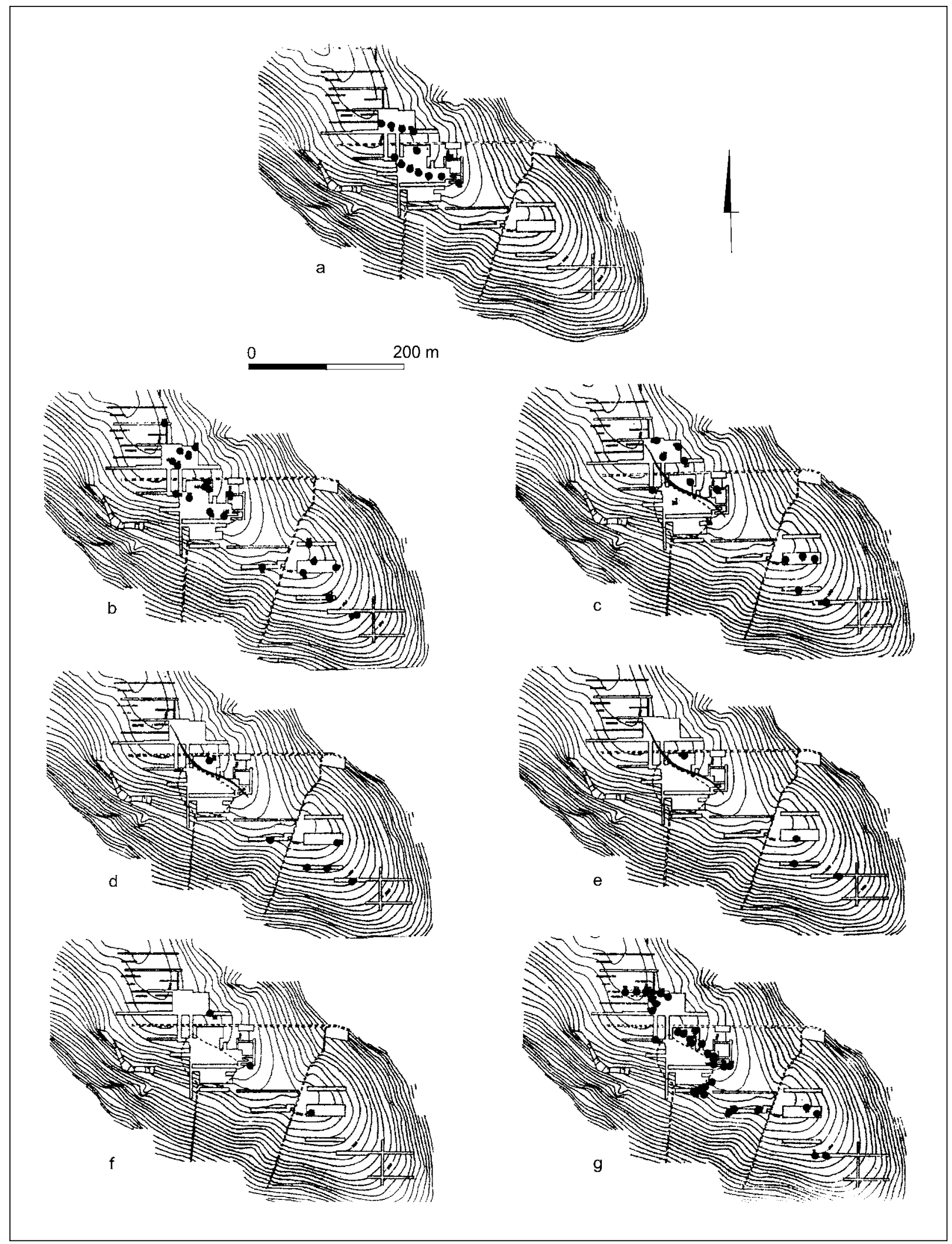

Fig. 1. Iwanowice, the 'Babia Góra I/II' site. a - features dated to the $1^{\text {st }}$ building phase; $b$ - features dated to $2^{\text {nd }}$ building phase; $\mathrm{c}$ - features dated to $3^{\text {rd }}$ building phase; $\mathrm{d}$ - features dated to $4^{\text {th }}$ building phase; $\mathrm{e}-$ features dated to $5^{\text {th }}$ building phase; $\mathrm{f}$ - features dated to $6^{\text {th }}$ building phase; $\mathrm{g}$ - features dated to $2^{\text {nd }}$ building phase (after Kadrow 1991). 


\section{IWANOWICE, SITE BABIA GÓRA (KRAKOW DISTRICT)}

Sites within Iwanowice microregion were investigated in the years 1967-1981. It comprised a few settlements, two cemeteries and many settlements (Kadrow 1991; Kadrow/Machnik/Machnik 1992). The main settlement was situated in loess upland, at the fork of upper Dłubnia (left-hand tributary of upper Vistula) and Minóżka rivers. Pottery stylistics and radiocarbon dates indicate that the settlement was inhabited for the whole time of the development of Mierzanowice culture: in proto, early, classical and late phases. No traces of dwelling houses or utility buildings were preserved. Pioneer analytical studies proved that every farmstead, besides the late phase, was accompanied by trapezoid or sack-like pit/cellar (Kadrow 1991).

In the first building phase, farmsteads were concentrated in regular lenticular shaped structure 130 $\mathrm{m}$ long and $60 \mathrm{~m}$ wide (Fig. 1). One farmstead was situated in the middle of a 'central yard'. In the second phase, farmsteads still created closed spatial arrangement covering much bigger area $\left(350-360 \mathrm{~m}^{2}\right)$. In the third, fourth and fifth building phases settlement occupied the same area but its size and number of farmsteads systematically decreased. One can define the spatial layout in those phases as an axial one. In the course of a fourth phase, a cemetery started to be exploited and a ditch separating it from a settlement was dug out. Scant remains of objects of the sixth phase do not allow drawing wider conclusions. Radical changes of the way of spatial arrangement brought a seventh building phase. Objects were clustered in a few places. One farmstead was represented by a few trapezoid objects and not, as before, by one pit. Consequently, a radical change of spatial arrangement of the whole settlement occurred.

Above-mentioned observations allow estimating the number of farmsteads in following phases, distances between farmsteads and sizes of particular settlements. Taking into account insufficient area prospection, estimations are very unsure in some cases. In the Early Mierzanowice phase, following settlements with big amount of farmsteads situated on regular lenticular or oval plan covered relatively small area (phases I-III). In the oldest part, distances between trapezoid pits reflecting farmsteads were only $10 \mathrm{~m}$. Over time, the distance between farmsteads increased due to, as one can assume, increasing of farmsteads sizes and to the settlement thinning. By the end of classical phase (building phase V) the settlement was widespread but the buildings were quite dispersed in axial arrangement. In the last (VII) building phase the development became dense again and farmsteads covered relatively big area.

\section{TARGOWISKO, SITE 10, 11 (BOCHNIA DISTRICT)}

Multicultural site at Targowisko is situated on the headland extended into the valley of Raba, right-hand tributary of upper Vistula. It was examined in the years 2000-2010 as part of rescue excavations carried out by the Cracow Team for Archaeological Supervision of the Motorway Construction. Assemblages of the Mierzanowice culture have been examined and published (Górski 2015). Features were concentrated in two clusters - eastern (A) and western (B). None of the relics could be interpreted as dwelling houses or other above-ground buildings. The vast majority of pottery comes from the late phase of the Mierzanowice culture. Older sherds were found occasionally.

In the first, western (A) cluster nearly 100 pits were found, most of them trapezoid in section (Fig. 2). They occupy very densely the area of ca. $5000 \mathrm{~m}^{2}$. The stratigraphy of some examples show, that they are not simultaneous. One can presume that in one time only part of them was in use. Basically, only minor clusters of pits were identified in the agglomeration. However, some of them seem to be characteristically organized along a line. Taking into account very modest amount of pottery originating exclusively from the late phase of the Mierzanowice culture, one cannot propose credible model of functioning of this group of pits.

The eastern cluster (B) of pits is of different nature (Fig. 2). They are stretched along the NW-SE line, forming a strip a dozen meters wide and ca. $150 \mathrm{~m}$ long. Within this concentration one can distinguish minor clusters. They comprise from a few to a several dozen of pits. Similarly to recently described cluster, stratigraphic relations of objects were very rare. Single pottery sherds allow establishing of chronology for this cluster (besides one feature), analogically to the eastern cluster, for the late phase of the Mierzanowice culture. Very credible seems a possibility of successive development of each cluster and not simultaneous exploitation of all the (or the most of) features.

It is difficult to define a role of secluded objects situated in the zone between described clusters of features in the spatial arrangement of the site. In this part a few concentrations of sometimes hundreds of pottery sherds were recorded. Their relation to hundreds of remaining pits is unknown. As far as stylistic analysis is concerned, almost all features, where pottery was found, come from one, late stylistic phase. One can estimate its duration for 300 years (Kadrow/Machnik 1997, fig. 66). From that point of view we are dealing with relatively stable settlement structure. Investigated and registered picture is a result of settlement development of duration no 


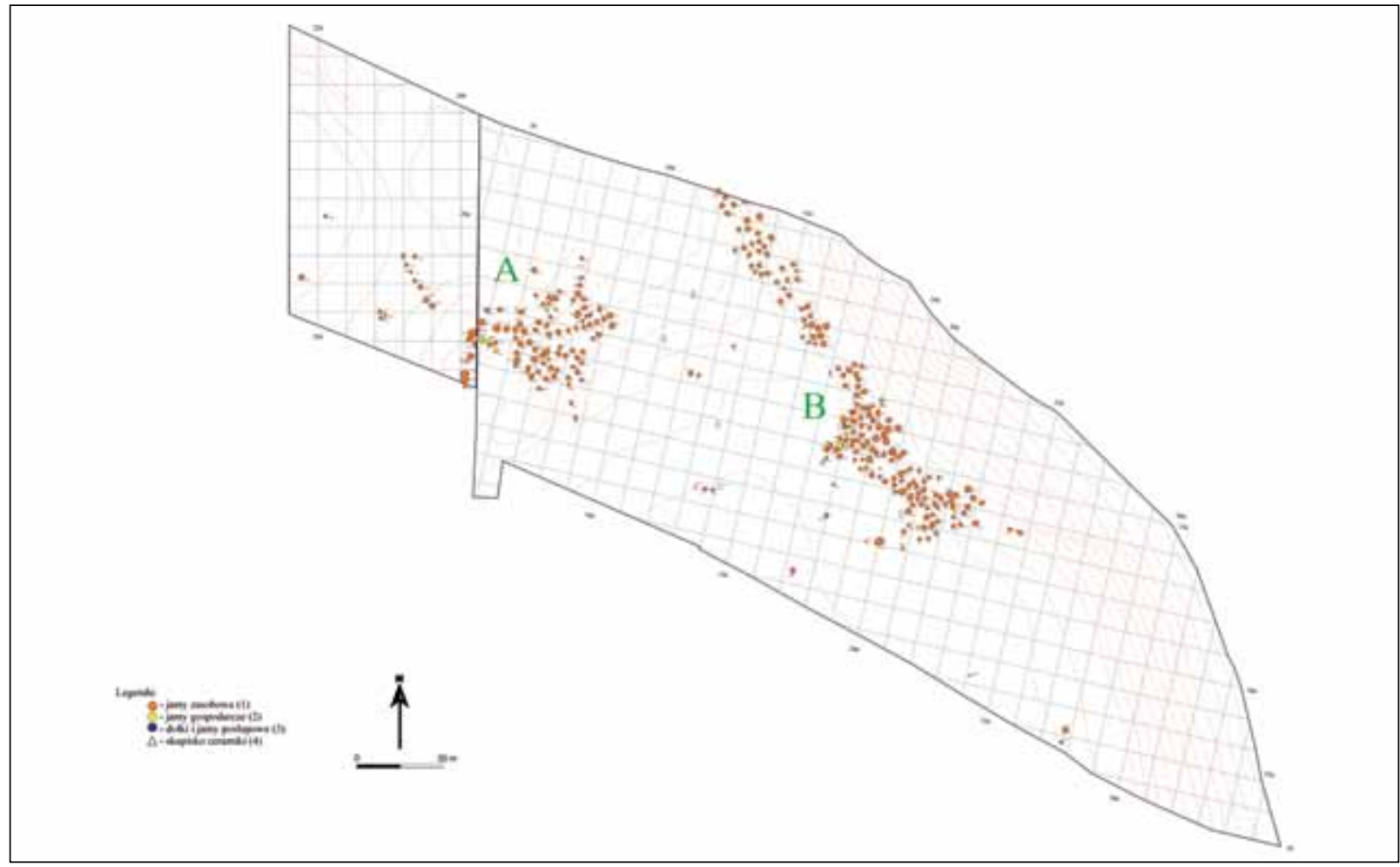

Fig. 2. Targowisko, site 10, 11. Distribution of features in claster A and B. 1 - storage pits; 2 - utility pits; 3 - postholes; 4 - concentration of ceramics.

longer than 300 years. Dwelling space could have been situated between clusters of features. Good arguments for that is its central position referring to both clusters and numerous pottery remains.

Similar situation was registered also in nearby site 16 at Targowisko. Compact clusters of several dozens of pits from the late phase of the Mierzanowice culture were discovered over there. Isolated clusters of a few features and linear spatial patterns were recorded as well (Włodarczak 2006, fig. 3). Both settlements are located $2 \mathrm{~km}$ from each other. Such patterns have not, so far, analogies in Mierzanowice culture, however, they resemble the picture registered in one of the settlements of Hatvan culture. The zone with numerous objects dug into the ground excludes the area with dwelling houses (Kienlin 2012, 279, fig. 19). It supports thesis about possible localization of dwelling houses between clusters $\mathrm{A}$ and $\mathrm{B}$ at Targowisko, sites 10 and 11.

\section{MODLNICA, SITE 5 (KRAKOW DISTRICT)}

Site 5 at Modlnica was explored in the years 2008-2010 in association with the construction of a fragment of the northern bypass of Krakow. It is situated on the southern, western and eastern slopes of a loess hill descending into Vistula valley. The hill is clearly elevated above surrounding area. The surface covering about $60-70$ ha with a few zones of intensive settlement was examined.

Features of Mierzanowice culture were concentrated in the western zone of the site (Fig. 3; 4). The pottery represents two stylistic phases - classical and late one. Spatial arrangement of features indicates that at the beginning of the Bronze Age the site was not intensely populated. Similarly to previously discussed sites no traces of above-ground dwellings were recorded.

In the northern part of the site a complex of twelve pits of Mierzanowice culture from a classic phase was distinguished. They cover an area of $600-700 \mathrm{~m}^{2}$. Pits had trough-like, rectangular or trapezoid profile. Another pattern was created by features from the late phase. Eight clearly isolated clusters were recorded, in which two to twelve different objects were identified. In particular the clusters of features were concentrated in an area of $100-200 \mathrm{~m}^{2}$. Cluster III differed from them. There were three separate groups of pits some $20 \mathrm{~m}$ apart from each other. Most probably each group is a relic of an operational zone of one farmstead. Accepting this interpretation leads to the conclusion that during a late phase of Mierzanowice culture the settlement was dispersed at the site. It is 


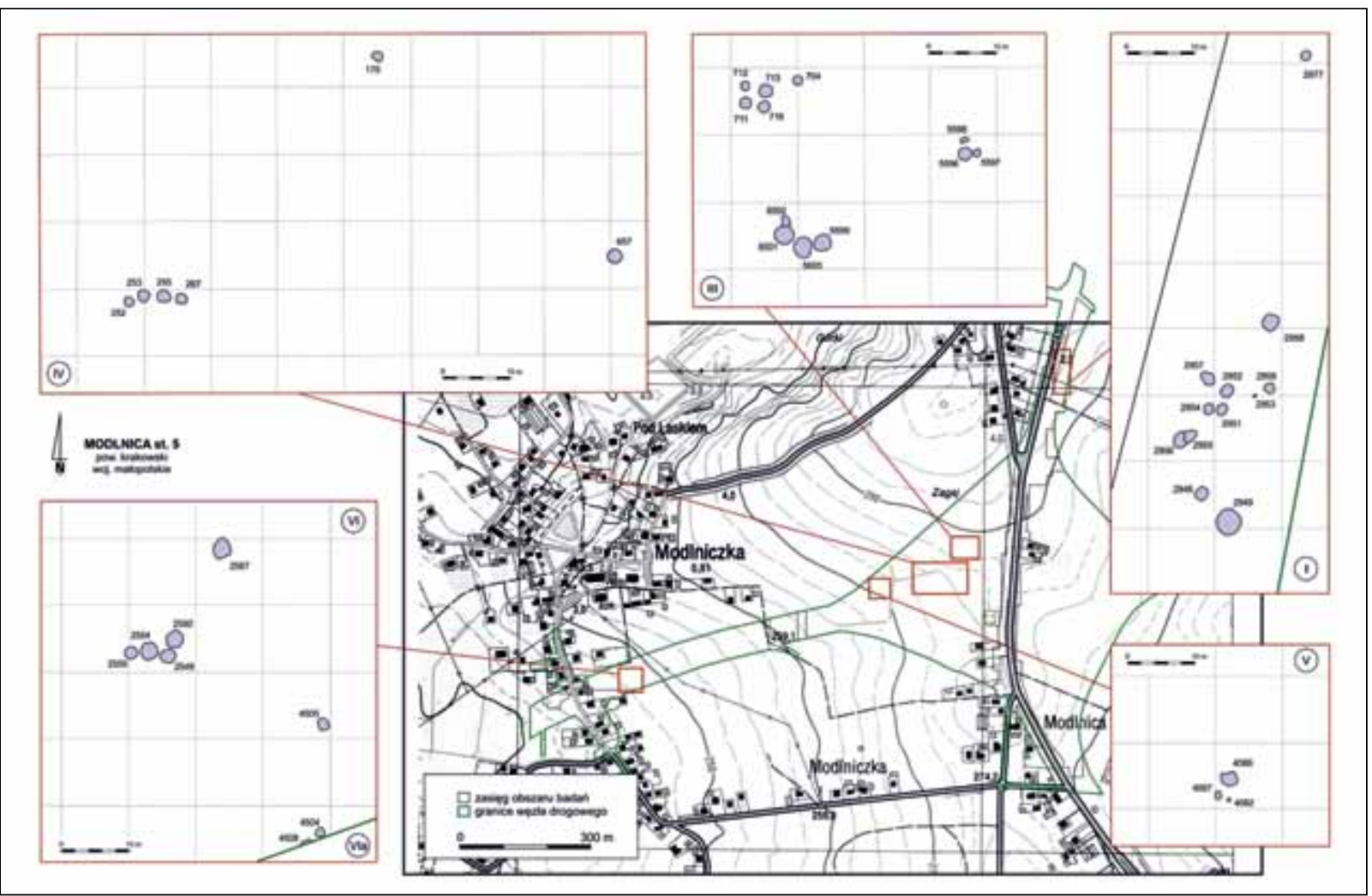

Fig. 3. Modlnica, site 5 (Krakow district). Distribution of features of Mierzanowice culture within the western and northern part of the explored area (concentrations I, III-VIa). Drawing by A. Zastawny (after Górski 2011).

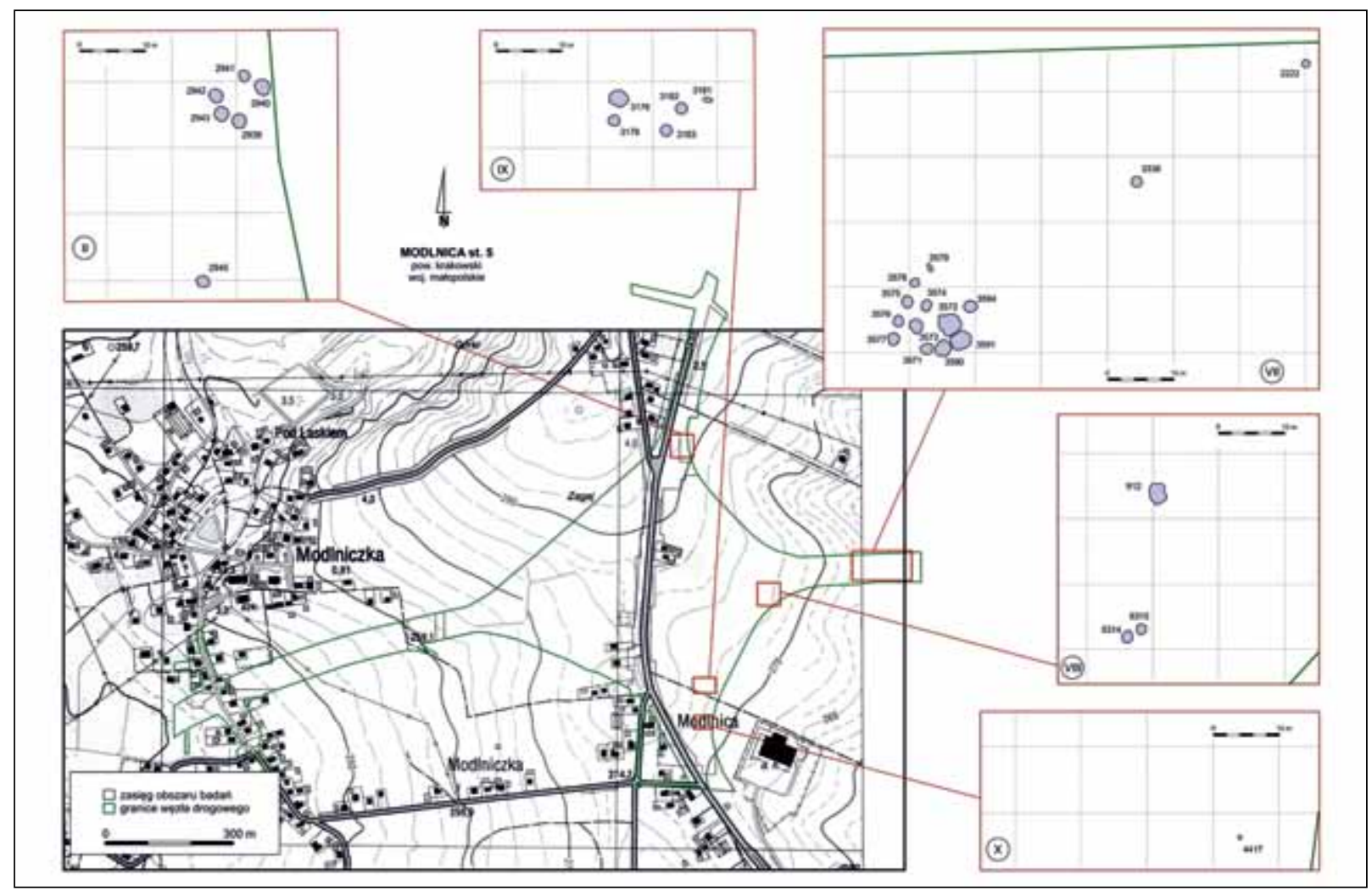

Fig. 4. Modlnica, site 5 (Krakow district). Distribution of features of Mierzanowice culture within the western and northern part of the explored area (concentrations II, VII-X). Drawing by A. Zastawny (after Górski 2011). 
difficult to say whether farmsteads functioned in the same time. Theoretically, three possibilities can be assumed: (1) chronological sequence of each of the group of pits, (2) simultaneous existence of all groups and (3) configuration taking into account a partial succession and partial synchronicity of groups. Most probably the arrangement of three farmsteads in the group III is simultaneous.

Regardless of chronological interpretation, we are certainly dealing with a dispersed settlement of 'hamlet' nature.

\section{ZAKRZOWIEC, SITE 6 (WIELICZKA DISTRICT)}

Multi-cultural site at Zakrzowiec is situated on a small elevation overlooking the valley of Podłężanka - small, right-hand tributary of Vistula. It was investigated in the years $2000-2008$ as part of rescue excavations carried out by the Cracow Team for Archaeological Supervision of the Motorway Construction. Assemblages of the Mierzanowice culture have been studied and published (Jarosz 2015). No traces have been found on the site which can be interpreted as relics of houses or other above-ground buildings. Artefacts are dated to early and late phases of Mierzanowice culture.

With an early phase one can associate two features $10 \mathrm{~m}$ one from each other and an isolated pit separated from them at a distance of $500 \mathrm{~m}$ (Fig. 5). Such arrangement of simultaneous features can indicate functioning in one time of at least two dwelling houses.

From a late phase come three clusters of pits spreading along the axis of a hump at a distance of $400 \mathrm{~m}$ (Fig. 5). Cluster I consisted of four pits embedded more or less in one axis. At a distance of $200 \mathrm{~m}$ to the west, following cluster of three storage pits was uncovered in axial arrangement stretched out for about $20 \mathrm{~m}$. Some $35 \mathrm{~m}$ from it, another object has been localized. All pits were trapezoid in section and had stratified fills. Particular clusters of objects represent probably remains of a dwelling area in the form of simultaneous dwelling houses or following building phases of spatially moving farmstead. Regardless of above-mentioned interpretation, it must be assumed that on that site, in the time of Mierzanowice culture development, the settlement was represented by single farmsteads.

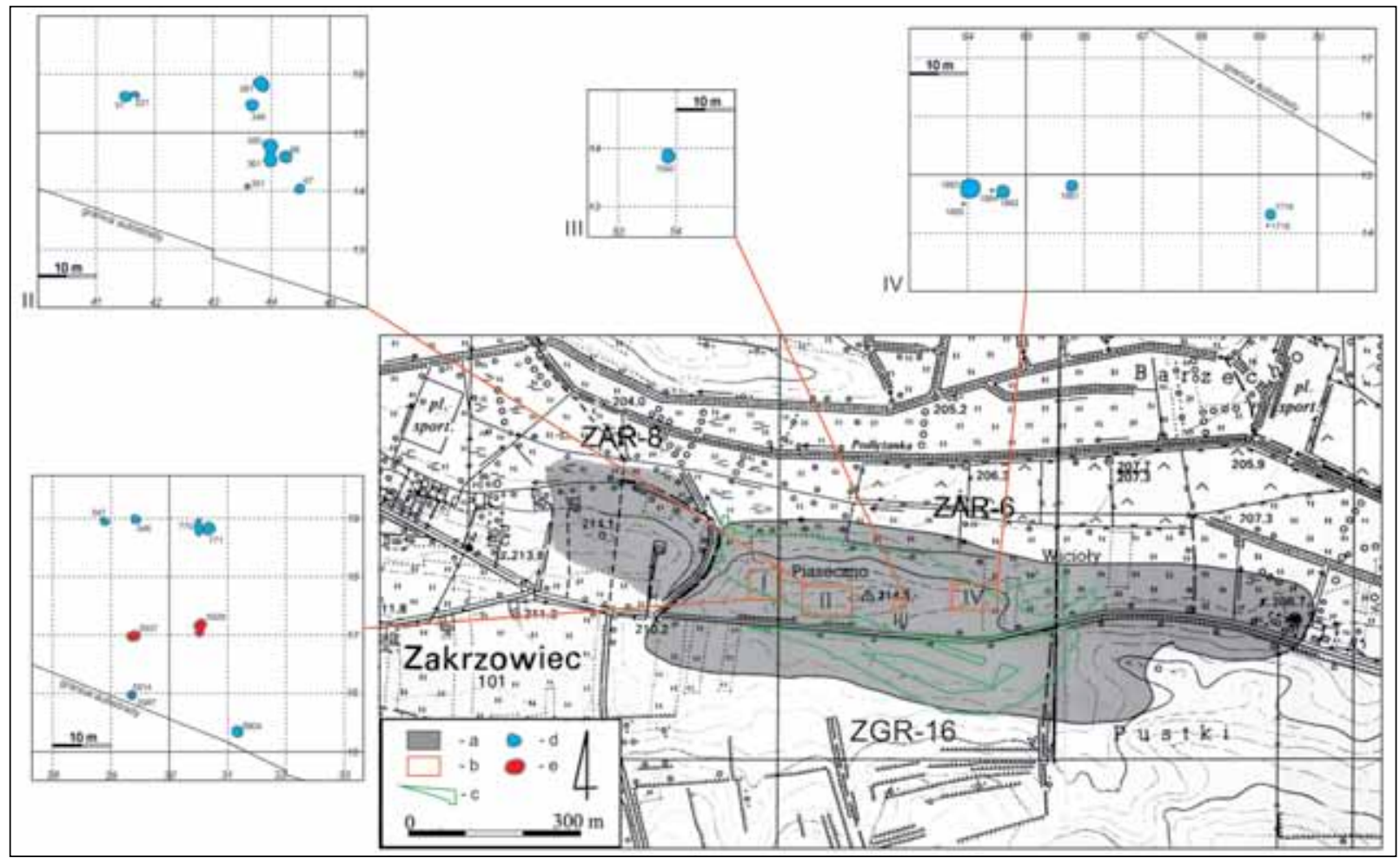

Fig. 5. Zakrzowiec, site 6 (Wieliczka district). Location of settlement zones of the Mierzanowice culture on the site. $\mathrm{a}$ - extent of the exploration sites; $\mathrm{b}$ - featured settlement zone; $\mathrm{c}$ - exploration area; $\mathrm{d}$ - features linked with the early phase of the Mierzanowice culture; e - features linked with the late phase of Mierzanowice culture (after Jarosz 2015). 


\section{CONCLUSION}

In the last years a few sites in the Krakow region were examined on a large scale. These studies provided us with reliable information concerning the spatial range, layout and inner structure of Mierzanowice culture settlements in different phases. One can propose several general conclusions:

1 . Basic feature is lack of remains of aboveground buildings.

2. Settlement sites are identified due to the existence of buildings dug into ground. Among them can be distinguished numerous big and deep trapezoid features with a stratified fill.

3. The exception is a settlement in Nowa Huta-Pleszów where no feature dug into the ground was found. Numerous pottery sherds were found in cultural layer.
4. The size of settlements is diversified - from single farmsteads to organized multi-farmstead structures. It is not related to different chrono$\log y$.

5. Farmsteads can be represented not only by one cellar/pit but also by a few or dozen of features.

6. Farmsteads forming a settlement can be situated on a regular oval plan or in axial arrangements.

7. In the case of settlements represented by hundreds of pits from one stylistic phase it is difficult to reconstruct its inner structure.

The analysis of Mierzanowice Culture settlement sites examined on a large scale shows great diversity in organization of settlement forms and lack of one specific spatial layout pattern for the farmsteads. Those differences do not dependent on chronology.

\section{LITERATURE}

Górski 2011 - J. Górski: Kompleks osad kultury mierzanowickiej w Modlnicy, stan. 5, pow. krakowski. In: J. Kruk/A. Zastawny (red.): Modlnica, st. 5. Od neolitu środkowego do wczesnej epoki brazu. Via Archaeologica. Źródła z badań wykopaliskowych na trasie autostrady A4 w Małopolsce. Kraków 2011, 463-511.

Górski 2015 - J. Górski: Osady kultury mierzanowickiej na stanowiskach 10 i $11 \mathrm{w}$ Targowisku, pow. wielicki. In: J. Górski/P. Jarosz (red.): Wielofazowe osady kultury mierzanowickiej w Targowisku i Zakrzowcu. Via Archaeologica. Źródła z badań wykopaliskowych na trasie autostrady A4 w Małopolsce. Kraków 2015, 33-140.

Jarosz 2015 - P. Jarosz: Osadnictwo kultury mierzanowickiej na stanowisku $6 \mathrm{w}$ Zakrzowcu, pow. wielicki. In: J. Górski/P. Jarosz (red.): Wielofazowe osady kultury mierzanowickiej w Targowisku i Zakrzowcu. Via Archaeologica. Źródła z badań wykopaliskowych na trasie autostrady A4 w Małopolsce. Kraków 2015, 183-216.

Jaśkowiak 1999 - P. Jaśkowiak: Materiały z wielukulturowego stanowiska 99 (1) w Dziekanowicach, woj. kieleckie. Typescript of master's thesis stored in the Institute of Archaeology UMCS in Lublin. Lublin 1999.

Kadrow 1991 -S. Kadrow: Iwanowice, stanowisko Babia Góra, cz. I. Rozwój przestrzenny osady z wczesnego okresu epoki brąu. Kraków 1991.

Kadrow 1995 - S. Kadrow: Gospodarka i społeczeństwo. Wczesny okres epoki brazu w Małopolsce. Kraków 1995.

Kadrow/Machnik 1997 - S. Kadrow/J. Machnik: Kultura mierzanowicka. Chronologia, taksonomia i rozwój przestrzenny. Kraków 1997.

Kadrow/Machnik/Machnik 1992 - S. Kadrow/A. Machnik/ J. Machnik: Iwanowice, stanowisko Babia Góra, cz. II.

Manuscript accepted 23. 6. 2020

Translated by Maryla Dryja

Súhrn preložila Anita Kozubová
Cmentarzysko z wczesnego okresu epoki brąu. Kraków 1992.

Kienlin 2012 - T. L. Kienlin: Patterns of Change, or: Perceptions Deceived? Comments on the Interpretation of Late Neolithic and Bronze Age Tell Settlement in the Carpathian Basin. In: T. L. Kienlin/A. Zimmermann (eds.): Beyond Elites. Alternatives to Hierarchical Systems in Modelling Social Formations. International Konference at Ruhr-Universität Bochum, Germany, October 22-24, 2009. Teil 1. Bonn 2012, 251-310.

Kruk 1973 - J. Kruk: Studia osadnicze nad neolitem wyżyn lessowych. Wrocław 1973.

Machnik 1967 - J. Machnik: Stosunki kulturowe na przełomie neolitu i epoki brązu w Małopolsce (na tle przemian w Europie środkowej. In: W. Hensel (red.): Materiały do prahistorii ziem polskich. Część III. Epoka brazu. Zeszyt 1. Warszawa 1967.

Madej 1988 - P. Madej: Inwentarz ceramiczny grupy pleszowskiej kultury mierzanowickiej ze stanowiska w Krakowie-Pleszowie IV/20. Materiaty Archeologiczne Nowej Huty 21, 1988, 27-70.

Rydzewski 1986 - J. Rydzewski: Przemiany stref zasiedlenia na wyżynach lessowych zachodniej Małopolski w epoce brązu i żelaza, Archeologia Polski 31, 1986, 125-194.

Włodarczak 2006 - P. Włodarczak: Wyniki badań wykopaliskowych przeprowadzonych w latach 2003-2004 na stanowisku 16 w Targowisku, gm. Kłaj, woj. małopolskie. In: Z. Bukowski/M. Gierlach (red.): Raport 2003-2004. Wstępne wyniki konserwatorskich badań archeologicznych w strefie budowy autostrad w Polsce za lata 2003-2004. Zeszyty Ośrodka Ochrony Dziedzictwa Archeologicznego. Warszawa 2006, 585-592.

Jacek Górski dr hab. (DSc)

The Pontifical University of John Paul II in Krakow

Archaeological Museum in Krakow

ul. Kanonicza 25/ul. Senacka 3

PL - 31-002 Krakow

jacekgorski1500@gmail.com 


\title{
Malé a vel'ké sídliská mierzanovickej kultúry vo vysočine západného Malopol'ska
}

\author{
Jacek Górski
}

\section{SÚHRN}

Vel'kost’ a štruktúra sídlisk mierzanovickej kultúry, zachytených počas nedávnej rozsiahlej cestnej výstavby v oblasti sprašovej pahorkatiny Krakovska, sa javí ako značne diverzifikovaná.

Opierajúc sa hlavne o výsledky nedávnych výskumov bolo možné overit teórie o rozsahu „vel"kých" a "malých" sídiel mierzanovickej kultúry a dospiet k niekol'kým nasledovným záverom.

1. Pre sídliská je charakteristický sporadický výskyt nadzemných objektov - nezachovali sa žiadne stopy po obydliach či hospodárskych objektoch.

2. Sídliská sa podarilo zachytit na základe zahĺbených objektov, medzi ktorými prevažujú vel'ké a hlboké objekty lichobežníkovitého pôdorysu so stratifikovanou výplňou. Tie sú funkčne interpretované ako pivnice.

3. Výnimkou je sídlisko v Nowej Hute-Pleszówe, kde neboli doložené žiadne zahĺbené objekty. V kultúrnej vrstve sídliska sa ale našiel početný keramický materiál.
4. Vel'kost' sídlisk je diverzifikovaná a nie je podmienená chronologicky - sledujeme tu výskyt ako menších usadlostí tak aj organizovaných štruktúr viacerých usadlostí (obr. 1:3-5).

5. Jednotlivé usadlosti môžu byt̉ reprezentované nielen jednou pivnicou/jamou, ale aj niekol'kými alebo desiatkami objektov (obr. 1: g; 3: III; 4: II, VII).

6. Usadlosti tvoriace jedno sídlisko môžu byt’ situované do priestoru pravidelného oválneho tvaru, alebo sú usporiadané do osi (obr. 1: a, f; 5: IV).

7. V prípade sídlisk so stovkami jám z jednej fázy osídlenia je tažké zrekonštruovat ich vnútornú štruktúru (obr. 2). Zdá sa, že tá čast' sídliska so zahíbenými objektmi sa neprekrýva s jeho obytnou častou (Kienlin 2012, 279, obr. 19).

Výsledky analýzy početných sídlisk mierzanovickej kultúry poukazujú na značnú rozmanitost’ foriem organizácie osídlenia a na absenciu jedného typu priestorového usporiadania usadlostí. Táto rozmanitost’ nie je podmienená chronologicky. 